\title{
The Impact of a Non-Functional Thyroid Receptor Beta upon Triiodotironine- Induced Cardiac Hypertrophy in Mice
}

\author{
Güínever Eustáquio do Império ${ }^{a}$ Isalira Peroba Ramos ${ }^{b}$ Letícia Aragão Santiago ${ }^{a}$ \\ Guilherme Faria Pereira ${ }^{a}$ Norma Aparecida dos Santos Almeidac Cesar Seigi \\ Fuziwara $^{d}$ Carmen C. Pazos-Moura ${ }^{\mathrm{e}}$ Edna Teruko Kimurad \\ Emerson Lopes Olivares ${ }^{c}$ Tania Maria Ortiga-Carvalho ${ }^{a}$ \\ aLaboratório de Endocrinologia Translacional, IBCCF, UFRJ, Rio de Janeiro, bDepartamento de \\ Radiologia, Hospital Universitário Clementino Fraga Filho, UFRJ; Laboratório de Cardiologia Celular e \\ Molecular, IBCCF, UFRJ, Rio de Janeiro, 'Departamento de Ciências Fisiológicas, IB, UFRuralRJ, Rio de \\ Janeiro, 'Laboratório de Biologia Molecular da Glândula Tiroide, ICB, USP, São Paulo, eLaboratório de \\ Endocrinologia Molecular, IBCCF, UFRJ, Rio de Janeiro, Brasil
}

\section{Key Words}

Thyroid Hormone $\cdot$ Cardiac hypertrophy $\bullet$ Thyroid hormone receptor $•$ MicroRNA $\bullet$ Transgenic mice

\begin{abstract}
Background/Aims: Thyroid hormone (TH) signalling is critical for heart function. The heart expresses thyroid hormone receptors (THRs); THR $\alpha 1$ and THR $\beta 1$. We aimed to investigate the regulation mechanisms of the THR $\beta$ isoform, its association with gene expression changes and implications for cardiac function. Methods: The experiments were performed using adult male mice expressing TR ${ }^{\triangle 337 T}$, which contains the $\triangle 337 T$ mutation of the human THRB gene and impairs ligand binding. Cardiac function and RNA expression were studied after hypoor hyperthyroidism inductions. T3-induced cardiac hypertrophy was not observed in TR $\beta^{\triangle 337 T}$ mice, showing the fundamental role of THR $\beta$ in cardiac hypertrophy. Results: We identified a group of independently regulated THR $\beta$ genes, which includes Adrb2, Myh7 and Hcn2 that were normally regulated by T3 in the TR $\beta^{\Delta 337 T}$ group. However, Adrb1, Myh6 and Atp2a2 were regulated via THR $\beta$. The TR $\beta^{\triangle 337 T}$ mice exhibited a contractile deficit, decreased ejection fraction and stroke volume, as assessed by echocardiography. In our model, miR-208a and miR-199a may contribute to THR $\beta$-mediated cardiac hypertrophy, as indicated by the absence of T3-regulated ventricular expression in TR ${ }^{\Delta 337 T}$ mice. Conclusion: THR $\beta$ has important role in the regulation of specific mRNA and miRNA in T3-induced cardiac hypertrophic growth and in the alteration of heart functions.

Tania M. Ortiga-Carvalho

Laboratório de Endocrinologia Translacional, Instituto de Biofísica Carlos Chagas Filho, Universidade Federal do Rio de Janeiro, Cidade Universitária, Rio de Janeiro, (Brasil) E-Mail taniaort@biof.ufrj.br
\end{abstract}

KARGER 125 


\section{Cellular Physiology Cell Physiol Biochem 2015;37:477-490

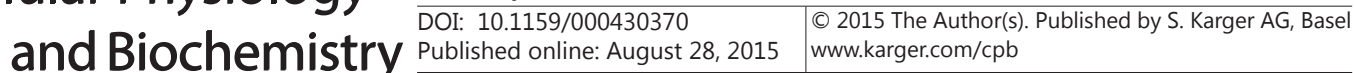 \\ Imperio et al.: T3-Induced Cardiac Hypertrophy}

\section{Introduction}

Thyroid hormone (TH) signalling is critical for proper heart development and function. Triiodothyronine (T3) and thyroxine (T4) can act directly on cardiomyocytes via genomic and non-genomic mechanisms. Additionally, T3 and T4 exert important indirect effects on cardiovascular functions by acting on the vascular system. After binding to nuclear receptors (thyroid hormone receptors; THRs), T3 modulates gene transcription, a function that occurs at specific sequences of DNA called TH-responsive elements in the promoter regions of T3 target genes [1]. Once bound to T3, THRs undergo conformational changes, favouring the release of corepressor proteins and the recruitment of coactivator molecules for the THRTRE complex [1], resulting in the increased transcription of many positively regulated T3responsive cardiac genes. In the absence of T3, THRs repress cardiac genes that are positively regulated by THs [2]. Moreover, T3 can bind to plasma membrane thyroid receptors, such as integrin $\alpha_{v} \beta_{3}[3,4]$, activating quick-start signalling cascades, including phosphatidylinositol 3 '-kinase (PI3K) and mitogen-activated protein kinase (MAPK) [5], which can regulate ribosomal biogenesis and protein translation and modulate the activity of membrane ions transporters, among other actions [6]. Additionally, non-genomic TH activation can interact with the genomic effects and contribute towards an overall effect on the heart $[7,8]$.

One of the most important and classic T3 effects on the heart is the induction of cardiac hypertrophy [9]. T3-induced hypertrophy is accompanied by a compensated cardiac functional response, which is primarily based on increased activities and expressions of proteins, such as sarcoplasmic reticulum calcium-activated ATPase (SERCA2, Atp2a2), a protein responsible for calcium re-uptake during diastole and increasing the relaxation rate. T3-induced hypertrophy is also accompanied by an increased expression of $\alpha$-myosin heavy chain ( $\alpha$-MHC, i.e., the fast myosin having higher ATPase activity, Myh6) and a reduced expression of $\beta$-MHC (i.e., the slow myosin, Myh7). As a characteristic response to a stimulusinducing adaptive hypertrophy, these effects improve cardiac contractility [10].

Additionally, T3 regulates the expression of specific genes implicated in the control of normal growth and prevents the expression of foetal gene patterns, characteristic of pathological cardiac hypertrophy $[11,12]$. This regulation is dependent on the THRs, suggesting their important role in the induction of cardiac hypertrophy by T3 $[1,13]$. THRs are encoded by two distinct genes in rodents: Thra and Thrb. Through alternative splicing, these genes have at least four active isoforms, THR $\alpha 1, \beta 1, \beta 2$ and $\beta 3$ [1]. These isoforms are expressed in various amounts in different tissues and exert varied functions in each [1418]. Most of the effects of T3 on the heart are suggested to occur via THR $\alpha 1$ [19-21], which is the predominant receptor isoform expressed in cardiac tissue. However, in T3-induced hypertrophy, growth is suggested to occur via THR $\beta 1$ signalling $[13,22]$.

To further study the mechanism of the THR $\beta$ pathway, we used transgenic mice bearing the $\Delta 337 \mathrm{~T}-T h r b$ mutation. These animals have a point mutation in the ligand-binding domain, rendering THR $\beta$ incapable of binding to T3 because it is constitutively associated with corepressors and exerts a potent dominant negative effect on the function of normal THRs $[23,24]$.

Additionally, microRNAs (miRNAs) are currently being studied as novel cardiac hypertrophy key regulators. miRNAs are approximately 22 nucleotides in length, singlestranded, non-coding RNAs that regulate protein expression through Watson-Crick base pairing between the miRNA 'seed region' and sequences commonly located in the 3' untranslated regions (UTRs) of specific mRNA targets [25]. Noteworthy studies have addressed their potential targets and mechanisms of action in the heart [26-30]. However, little is known about their interaction with THRs in T3-induced cardiac hypertrophy.

Therefore, our study aimed to investigate whether the role of the THR $\beta$ isoform in the regulation of T3-induced cardiac hypertrophy involves changes in the expression of specific miRNAs. 


\section{Cellular Physiology Cell Physiol Biochem 2015;37:477-490 and Biochemistry \begin{tabular}{l|l} 
DOI: 10.1159/000430370 & (c) 2015 The Author(s). Published by S. Karger AG, Basel \\
www.karger.com/cpb
\end{tabular} \\ Imperio et al.: T3-Induced Cardiac Hypertrophy}

\section{Materials and Methods}

Ethical Approval

This study was approved by the ethics committee of the Health Sciences Centre, Federal University of Rio de Janeiro (\#IBCCF1002).

Animals

Eight-to-twelve-week-old male mice were used. These mice were wild type (TR $\beta^{\text {WT }}$ ) or homozygous (TR $\beta^{\Delta 337 T}$ ) for the $\Delta 337 \mathrm{~T}-T h r b$ mutation, and they were generated as previously described, based on a natural human mutation [24]. The genotyping of tail DNA was performed by a mismatched polymerase chain reaction (PCR) as described in our previous study [31]. Mice were maintained in plastic cages and on absorbent bedding under controlled temperature $\left(24 \pm 1^{\circ} \mathrm{C}\right)$ and lighting $(12 \mathrm{~h} \mathrm{light} /$ dark cycle $)$ conditions, with lights on at 07:00 h. Mice had free access to filtered water and standard chow (Bio-Tec, RJ, Brazil) during all experimental procedures, except during the induction of hypothyroidism, as described below.

A total of 62 TR $\beta^{\mathrm{WT}}$ and 41 TR $\beta^{\Delta 337 \mathrm{~T}}$ mice were used in all experiments. Thirteen TR $\beta^{\mathrm{WT}}$ and 11 TR $\beta^{\Delta 337 \mathrm{~T}}$ mice were sacrificed by decapitation, and their sera and hearts were collected and stored at $-70^{\circ} \mathrm{C}$ for baseline evaluation.

\section{Evaluation of mRNA expression in hypo- and hyperthyroidism}

From previous works, TR $\beta^{\mathrm{WT}}$ and TR $\beta^{\Delta 337 \mathrm{~T}}$ mice were shown to present different TH levels at baseline $[13,24,31]$. Therefore, to study gene expression under the same thyroid status, the TH serum concentrations of both genotypes were matched by subjecting the mice to hypothyroidism induction or hyperthyroidism induction. Hypothyroidism was induced by 5 weeks of treatment with $0.15 \%$ PTU (5-propyl-2-thiouracil; Sigma-Aldrich, SP, Brazil) added to the diet (Hypo). Fifteen TR $\beta^{W T}$ and thirteen TR $\beta^{\Delta 337 T}$ mice were subject to this PTU treatment. Hyperthyroidism was induced by 3 weeks of daily T3 (3,5,3'Triiodo-L-Thyronine; SigmaAldrich, SP, Brazil) subcutaneous (s.c.) injections, at increasing doses of $0.2,0.5 \mathrm{and} 1.0 \mu \mathrm{g} / 100 \mathrm{~g}$ body weight (bw), after the initial 5 weeks of hypothyroidism induction (Hyper). Hypothyroidism and hyperthyroidism protocols were followed in accordance to recent guidelines published by a group of thyroid experts [32, 33]. Twenty-four hours after the final injection of vehicle or T3, mice were sacrificed by decapitation, and their sera and hearts were collected and stored at $-70^{\circ} \mathrm{C}$ until evaluation.

\section{RNA extraction}

Total RNA was extracted from samples (atria and ventricles) by standard methods (TRIzol Reagent; Life Technologies, CA, USA). The total RNA was divided into aliquots for mRNA and miRNA quantification and for miRNA microarray analyses.

\section{Quantification of $m R N A$}

Total RNA was reverse transcribed using $1 \mu \mathrm{g}$ of RNA and a Reverse Transcription kit (Promega, WI, USA). Quantitative reverse transcription (RT)-PCR was used to analyse the mRNA expressions of $\alpha$ and $\beta$ myosin heavy chain (Myh6 and Myh7), $\beta 1$ and $\beta 2$ adrenergic receptors (Adrb1 and Adrb2), sarcoplasmic reticulum $\mathrm{Ca}^{++}$-ATPase 2a (Serca2, Atp2a2) and hyperpolarization-activated cyclic nucleotide-gated channels 2 (Hcn2). Real-time RT-PCR was performed using the Master Cycler Realplex system (Eppendorf, Germany) and Maxima SYBR Green/ROX qPCR Master Mix 2X (Fermentas, MA, USA). Intron spanning primers were synthesized by Integrated DNA Technologies (IA, USA) and were obtained from references as shown in Table 1. 36B4 (RplpO) was used as the endogenous control as previously described by us and validated in the heart by others [33-35]. Samples were analysed in duplicate, and the cycle parameters were as follows: $50^{\circ} \mathrm{C}$ for $2 \mathrm{~min}$ and $95^{\circ} \mathrm{C}$ for $10 \mathrm{~min}$, followed by 40 cycles at $95^{\circ} \mathrm{C}$ for $15 \mathrm{~s}, 60^{\circ} \mathrm{C}$ for $30 \mathrm{~s}$, and $72^{\circ} \mathrm{C}$ for 45 $\mathrm{s}$. The product purity was confirmed by agarose gel and melting curve analyses, and the efficiency of each assay was confirmed and accepted when near $100 \%$. Changes in the mRNA expression were calculated from

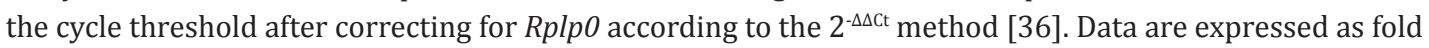
induction over the control group as stated in the figure legends.

\section{MicroRNA analysis}

For the miRNA expression analysis, 10 ng of total RNA was reverse transcribed using a TaqMan MicroRNA Reverse Transcription kit (Applied Biosystems, CA, USA) and RT primers provided with the miR-1 and miR-208a TaqMan miRNA Assay (Applied Biosystems, CA, USA) according to the manufacturer's 


\section{Cellular Physiology Cell Physiol Biochem 2015;37:477-490 \begin{tabular}{ll|l} 
DOI: 10.1159/000430370 & $\begin{array}{l}\text { O } 2015 \text { The Author(s). Published by S. Karger AG, Basel } \\
\text { www.karger.com/cpb }\end{array}$
\end{tabular} \\ Imperio et al.: T3-Induced Cardiac Hypertrophy}

instructions. The miRNA expression was detected from the cDNA product using a TaqMan Universal PCR Master Mix No AmpErase UNG (Applied Biosystems, CA, USA) and the TaqMan miRNA Assay. Small nuclear RNA U6 (SNRNA1973, Applied Biosystems, CA, USA) was used for the normalization of data. Amplification and detection were performed using the Master Cycler Realplex system (Eppendorf, Germany). Relative quantifications were calculated according to the Pfaffl method [37].

Microarray analyses were performed by LC Sciences (TX, USA) using $2 \mu$ g of total RNA from the wild-type $\left(\mathrm{TR} \beta^{\mathrm{WT}}\right)$ or homozygous $\left(\mathrm{TR} \beta^{\Delta 337 \mathrm{~T}}\right)$ group at the end of the hyperthyroidism protocol.

\section{Functional studies}

$\mathrm{TR} \beta^{\mathrm{WT}}$ and TR $\beta^{\Delta 337 \mathrm{~T}}$ mice were studied at base-
Table 1. Primers used in qPCR

\begin{tabular}{lcc}
\hline Srimers & \multicolumn{2}{c}{ Sequence } \\
\hline Rplp0 F & TGT TTG ACA ACG GCA GCA TTT & {$[34]$} \\
Rplpo R & CCG AGG CAA CAG TTG GGT & \\
Adrb1 F & GCT GCA GAC GCT CAC CA & {$[59]$} \\
Adrb1 R & GCG AGG TAG CGG TCC AG & \\
Adrb2 F & CAC AGT CAT TGC CAA GTT CG & {$[59]$} \\
Adrb2 R & CGG GCC TTA TTC TTG GTC AGC & \\
Atp2a2 F & ATA CTG ATG GCA CTT CAC TGG & {$[60]$} \\
Atp2a2 R & AAG ACA GGC ACA CTT ACC AC & \\
Hcn2 F & GAC AAT TTC AAC GAG GTG CTG & {$[61]$} \\
Hcn2 R & TGA TGG CAT TCT CCT GGT TG & \\
Myh7 R & ACA TAC TCG TTC CCC ACC TTC & {$[34]$} \\
Myh7 F & AGC TGA CAG GGG CCA TCA T & \\
Myh6 R & CTC CGG ATT CTC CGG TGA T & {$[34]$} \\
Myh6 F & CCT CCT CAC ATC TTC TCC ATC TCT & \\
\hline
\end{tabular}

line and under hypo- and hyperthyroid conditions. After 5 weeks of treatment with $0.15 \%$ PTU added to food (HYPO), mice received daily s.c. injections for 2 weeks of T3 at $50 \mu \mathrm{g} / 100 \mathrm{~g}$ bw (HYPER) while maintaining the PTU treatment. At the end of the experimental protocol, mice underwent echocardiography [38] and electrocardiography (ECG) as described below.

\section{Echocardiography analysis}

Animals were anesthetized with $1.5 \%$ isoflurane gas, dichotomized in the precordium region and examined by Vevo 770 (VisualSonics, OT, Canada) using a 30-MHz transducer. Cardiac geometries and the systolic and diastolic functions of the left ventricles were assessed using one- and two-dimensional modes. The determination of the left ventricular systolic function was established through an analysis of the ejection fraction, which was calculated using a modified Simpson's method [39]. Using the aid of a cursor, the analysis was delimited to the entire left ventricular cavity in systole and diastole. Next, the equipment automatically calculated the stroke and end diastolic volumes, thereby providing the ejection fraction. Doppler echocardiography analysis was performed by a single experienced expert who was unaware of the origin of the animals or the experimental groups to which they belonged. All values were obtained according the recommendations of the American Society of Echocardiography [38].

\section{Electrocardiogram recording}

Records were obtained in conscious mice 48 hours after the implantation of electrodes. Records were started 15 min after linking the connector to the data acquisition system (3A9 amplifier; Tektronix/TL-2 A/D Interface; Axon Instruments, CA, USA). The surgical procedures and ECG recordings were carried out as previously described in detail by our group [40].

The hypothyroid and hyperthyroid mice were sacrificed, and the hearts were collected and weighed. The tibia lengths were measured to obtain the relative heart weight [heart weight (mg)/by tibia length [17, $18,26]]$, an indirect parameter used to assess cardiac hypertrophy.

\section{Serum hormone measurements}

Specific radioimmunoassay [39] commercial kits were used to measure the total triiodothyronine (T3) and the total thyroxine (T4) (MP Biomedicals ${ }^{\mathrm{TM}}$, CA, USA) by the solid phase method. Thyroid-stimulating hormone (TSH) expression was measured by the double-antibody method, using NIDDK mouse TSH antiserum (AFP98991), as previously described [41]. All samples were measured in duplicate and within the same assay.

\section{Statistical analysis}

Data were reported as the means \pm standard errors of the means (S.E.M.). The number of animals is indicated in the figure legends. Student's t-test was employed when comparisons were made for different genotypes, and a two-way analysis of variance (ANOVA) was employed when comparisons were made for 


\section{Cellular Physiology Cell Physiol Biochem 2015;37:477-490 \begin{tabular}{ll|l} 
DOI: 10.1159/000430370 & $\begin{array}{l}\text { O } 2015 \text { The Author(s). Published by S. Karger AG, Basel } \\
\text { wwww.karger.com/cpb }\end{array}$ \\
\cline { 2 - 4 }
\end{tabular} \\ Imperio et al.: T3-Induced Cardiac Hypertrophy}

Table 2. Baseline parameters of wild type $\left(\mathrm{TR} \beta^{\Delta 337 \mathrm{~T}}\right)$ and homozygous $\left(\mathrm{TR} \beta^{\Delta 337 \mathrm{~T}}\right)$ mice. EDD, end-diastolic diameter; RWT, relative wall thickness, end-systolic diameter (2* PWT(d)/ EDD); PWT(d), posterior wall thickness $\mathrm{N}=5-8$ animals/group

\begin{tabular}{lccc}
\hline & TR $\beta$ wt & TR $\beta \Delta 37 \mathrm{~T}$ & \\
\hline BW $(\mathrm{g})$ & $74.3 \pm 2.64$ & $78.5 \pm 0.95$ & NS \\
T4 $(\mu \mathrm{g} / \mathrm{dl})$ & $4.09 \pm 0.36$ & $>18$ & $\mathrm{P}<0.001$ \\
PWTs $(\mathrm{mm})$ & $0.89 \pm 0.01$ & $0.99 \pm 0.04$ & $\mathrm{NS}$ \\
EDD $(\mathrm{mm})$ & $3.77 \pm 0.25$ & $3.98 \pm 0.39$ & $\mathrm{NS}$ \\
RWT & $0.48 \pm 0.04$ & $0.51 \pm 0.04$ & $\mathrm{NS}$ \\
Left ventricular mass $(\mathrm{mg})$ & $97.8 \pm 6.85$ & $127.5 \pm 20.8$ & $\mathrm{NS}$ \\
End-systolic volume $(\mu \mathrm{L})$ & $55.5 \pm 2.33$ & $29.8 \pm 6.46$ & $\mathrm{P}<0.02$ \\
End-diastolic $(\mu \mathrm{L})$ & $55.8 \pm 2.40$ & $50.5 \pm 10.9$ & $\mathrm{NS}$ \\
Ejection Fraction $(\%)$ & $68.0 \pm 3.24$ & $65.6 \pm 3.33$ & $\mathrm{NS}$ \\
Stroke volume $(\mu \mathrm{L})$ & $37.8 \pm 0.85$ & $43.8 \pm 6.85$ & $\mathrm{NS}$ \\
\hline
\end{tabular}

different genotypes and for different treatments. Two-way ANOVAs were followed by Bonferroni multiple comparisons tests for the assessment of significance (Graph Pad Prism 6; GraphPad Software, Inc., CA, USA). Differences were considered to be significant at a $\mathrm{P} \leq 0.05$.

\section{Results}

Cardiac baseline gene expression

First, mice were studied at baseline. No differences were observed in weight, but the total serum T4 concentration was four times higher in the TR $\beta^{\Delta 337 \mathrm{~T}}$ mice than in the TR $\beta^{\mathrm{WT}}$ mice (Table 2). There were no differences in the ventricular mRNA expressions of Myh6 and Myh7 between the TR $\beta^{\mathrm{WT}}$ and TR $\beta^{\Delta 337 \mathrm{~T}}$ mice (Fig. 1B). However, the ventricular mRNA expressions of $A d r b 1$ and Adrb2 were significantly lower and higher, respectively $(\mathrm{P}<0.01$ and $\mathrm{P}<0.05)$ in the TR $\beta^{\Delta 337 \mathrm{~T}}$ mice compared with the TR $\beta^{\mathrm{WT}}$ mice (Fig. $1 \mathrm{~A}$ ). The TR $\beta^{\Delta 337 \mathrm{~T}}$ mice also showed significantly lower Atp2a2 ventricular mRNA expression $(\mathrm{P}<0.001)$ and significantly greater $H c n 2$ atrial mRNA expression $(\mathrm{P}<0.01)$ compared with the TR $\beta^{\mathrm{WT}}$ mice (Fig. 1A). As previously shown, at baseline, the TR $\beta^{\triangle 337 \mathrm{~T}}$ mice presented increased levels of T4 (Table 1) and T3 [13, 14, 24, 42-44]. Therefore, the observed differences seen here do not reflect the actual $\mathrm{TH}$ levels.

\section{Cardiac gene expression after hypo- and hyperthyroidism induction}

Mice were subjected to hypo- and hyperthyroidism induction to evaluate the role of THR $\beta$ in the absence and presence of T3 upon gene expression.

After PTU treatment, both groups presented undetectable serum concentrations of T4 (data not shown), decreased levels of total T3 (TR $\beta^{\text {WT }}$ Hypo: $45.4 \pm 8.6$ and TR $\beta^{\Delta 337 \mathrm{~T}}$ Hypo:

Fig. 1. Baseline parameters of wild-type $\left(\mathrm{TR} \beta^{\mathrm{WT}}\right)$ and homozygous $\left(\mathrm{TR} \beta^{\Delta 337 \mathrm{~T}}\right)$ mice. (A) Ventricle mRNA expression of AR- $\beta 1$ (Adrb1), AR- $\beta 2$ (Adrb2), and SERCA2 (Atp2a2) and atrial mRNA expression of HCN2 (Hcn2) in nine TR $\beta^{\text {wt }}$ and five TR $\beta^{\Delta 337 T}$ mice. (B) Ventricle mRNA expression of $\alpha$-MHC (Myh6) and $\beta$-MHC (Myh7) and the $\alpha$-MHC/ $\beta$-MHC (Myh6/ Myh7) ratio. The data are shown as the means of fold change \pm S.E.M. and represent the averages of three independent experiments. Differences were considered significant when $\mathrm{P}<0.05$. Line represents the expression level of TR $\beta^{\mathrm{WT}}$.

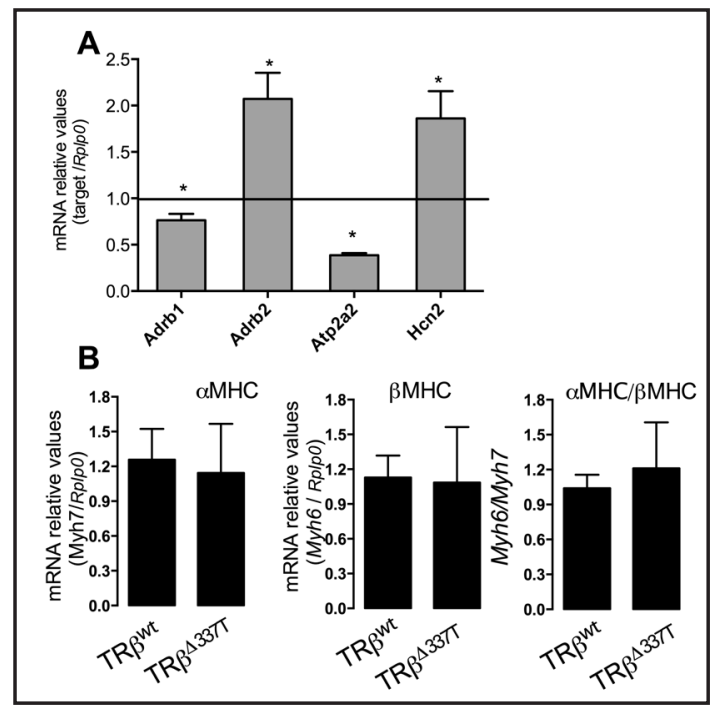


Fig. 2. Effect of thyroid hormone (TH) deficiency and excess on classic THresponsive genes in the heart. (A-C) Ventricular mRNA expression of AR$\beta 1$ (Adrb1), AR- $\beta 2$ (Adrb2) and SERCA2 (Atp2a2) and (D) atrial mRNA expression of HCN2 (Hcn2) in TR $\beta^{\text {wt }}$ and $\mathrm{TR} \beta^{\Delta 337 \mathrm{~T}}$ mice, according to qPCR analysis. The data are shown as the means of fold change \pm S.E.M. Data were normalized for each mRNA level relative to the hypothyroid TR $\beta^{\text {wt }}$ group. Same letters indicate similar means. Six to eight animals were evaluated in each group. Hypo PTU-treated mice, Hyper: PTU+T3-treated mice.
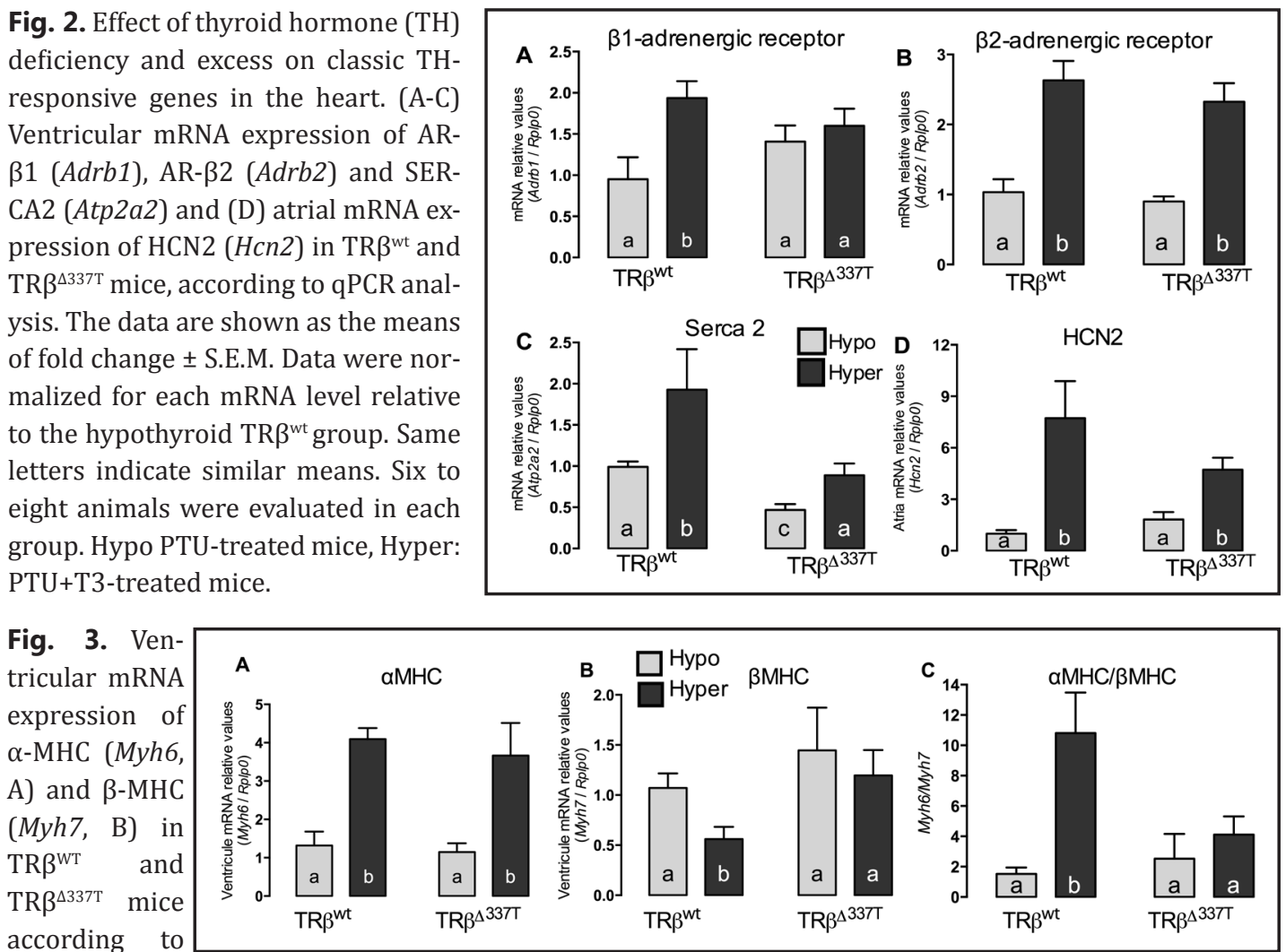

qPCR analysis. (C) $\alpha$-MHC/ $\beta$-MHC (Myh6/Myh7) ratio. The data are shown as the means of fold change \pm S.E.M. Data were normalized for each mRNA level relative to the hypothyroid TR $\beta^{\mathrm{wt}}$. Same letters indicate similar means. Six to eight animals were evaluated in each group. Hypo: PTU-treated mice, Hyper: PTU+T3treated mice.

$40.0 \pm 8.7 \mathrm{ng} / \mathrm{dL}$ ) and, importantly, elevated levels of TSH (above threshold detection; data not shown). After T3 treatment, TR $\beta^{\text {WT }}$ and TR $\beta^{\Delta 337 \mathrm{~T}}$ presented similar levels of T3 (78.8 \pm 4.5 and $100.6 \pm 9.0 \mathrm{ng} / \mathrm{dL}$ respectively). Thra and Thrb mRNA were also evaluated. No differences were seen regarding Thrb mRNA however, T3 treatment caused a decreased in Thra mRNA in both groups (data nor shown).

As expected, the TR $\beta^{\text {WT }}$ mice presented significantly greater mRNA ventricular expression levels of Adrb1 and Atp2a2 after T3 treatment $(\mathrm{P}<0.05)$; however, these effects were not significantly different in the TR $\beta^{\Delta 337 T}$ mice (Fig. $2 \mathrm{~A}$ and $\mathrm{C}$ ). Both mice groups presented significantly higher Adrb2 and Hcn2 mRNA expression levels $(\mathrm{P}<0.001)$ after T3 treatment (Fig. 2B and D). In addition, both the TR $\beta^{\mathrm{WT}}$ and TR $\beta^{\Delta 337 \mathrm{~T}}$ mice groups presented significantly higher Myh6 mRNA expression levels after T3 treatment (Fig. 3A, $\mathrm{P}<0.01$ ). However, only the $\mathrm{TR} \beta^{\mathrm{WT}}$ mice showed a significant reduction in Myh7 $(\mathrm{P}<0.05)$ after T3 treatment (Fig. 3A and B). Thus, as shown in Fig. $3 \mathrm{C}$, there was an increase in the $\alpha / \beta$-MHC ratio in the TR $\beta^{\mathrm{WT}}$ mice when comparing between the Hyper and Hypo groups $(\mathrm{P}<0.01)$. A similar increase was not observed in the TR $\beta^{\Delta 337 T}$ mice.

\section{Cardiac morphology and function assessment}

After the T3 treatment, the EDD did not change in the TR $\beta^{\mathrm{WT}}$ mice compared with the hypothyroid mice, a phenomenon that was not observed in the TR $\beta^{\Delta 337 T}$ mice (Table 3); on the contrary, EDD increased after T3 treatment. Although the PWT (d) and RWT were not significantly different among the groups, the RWT thickness increased in the TR $\beta^{\mathrm{WT}}$ mice and decreased in the TR $\beta^{\Delta 337 \mathrm{~T}}$ mice $(\mathrm{P}=0.06)$. These observed opposite effects induced by the T3 treatment resembled the concentric and eccentric hypertrophy in the TR $\beta^{\mathrm{WT}}$ and $\operatorname{TR} \beta^{\Delta 337 \mathrm{~T}}$ 
Table 3. Parameters recorded from the echocardiogram of wildtype $\left(\mathrm{TR} \beta^{\mathrm{WT}}\right)$ and homozygous $\left(\mathrm{TR}^{\Delta 337 \mathrm{~T}}\right)$ hypothyroid and hyperthyroid mice. EDD, end-diastolic diameter; RWT, relative wall

\begin{tabular}{lcccc}
\hline & \multicolumn{2}{c}{ TR $\beta^{\mathrm{wt}}$} & \multicolumn{2}{c}{ TR $\beta^{\Delta 337 \mathrm{~T}}$} \\
& HYPO & HYPER & HYPO & HYPER \\
\hline EDD $(\mathrm{mm})$ & $3.47 \pm 0.13$ & $3.95 \pm 0.40$ & $3.84 \pm 0.16$ & $4.24 \pm 0.13^{*}$ \\
RWT & $0.63 \pm 0.07$ & $0.71 \pm 0.27$ & $0.54 \pm 0.05$ & $0.35 \pm 0.02$ \\
PWT(d) $(\mathrm{mm})$ & $1.10 \pm 0.09$ & $1.24 \pm 0.28$ & $1.09 \pm 0.12$ & $0.87 \pm 0.11$ \\
\hline
\end{tabular}
thickness, end-systolic diameter (2* PWT(d)/EDD); PWT(d), posterior wall thickness. ${ }^{*} \mathrm{P}<0.05$ compared to hypothyroid TR $\beta^{\Delta 337 T}$. $n=3-11$ animals/group

\begin{tabular}{|c|c|c|c|c|c|}
\hline \multirow{2}{*}{$\begin{array}{l}\text { Table 4. Parameters } \\
\text { recorded from the } \\
\text { electrocardiogram }\end{array}$} & & \multicolumn{2}{|c|}{ TR $\beta^{w t}$} & $\mathrm{TR} \beta \Delta 337 \mathrm{~T}$ & \multirow[b]{2}{*}{ HYPER } \\
\hline & & HYPO & HYPER & HYPO & \\
\hline (ECG) of wild-type & P-wave (ms) & $12.93 \pm 0.49$ & $8.02 \pm 0.13^{*}$ & $12.03 \pm 1.08$ & $11.64 \pm 0.68$ \\
\hline$\left(\mathrm{TR} \beta^{\Delta 337 \mathrm{~T}}\right)$ and ho- & PR Interval (ms) & $32.78 \pm 1.65$ & $27.84 \pm 1.96$ & $33.60 \pm 1.45$ & $29.42 \pm 1.54$ \\
\hline mozygous $\left(\mathrm{TR} \beta^{\Delta 337 \mathrm{~T}}\right)$ & QRS Duration (ms) & $19.75 \pm 1.92$ & $19.53 \pm 2.12$ & $21.66 \pm 1.04$ & $17.78 \pm 1.13$ \\
\hline HYPO and HYPER & QT Interval (ms) & $30.13 \pm 2.40$ & $27.13 \pm 0.24$ & $30.02 \pm 2.92$ & $24.28 \pm 3.64$ \\
\hline roup mice. ${ }^{*} \mathrm{P}<0.05$. & T-Wave (ms) & $18.50 \pm 1.82$ & $14.63 \pm 0.84$ & $19.18 \pm 2.91$ & $12.92 \pm 3.20$ \\
\hline & Heart Rate (bpm) & $528.7 \pm 29.49$ & $655.8 \pm 22.86^{*}$ & $553.4 \pm 51.79$ & $677.6 \pm 45.94^{*}$ \\
\hline
\end{tabular}

Fig. 4. Cardiac function as sessment, by echocardiography [38], of $\operatorname{TR} \beta^{\mathrm{WT}}$ and $\mathrm{TR} \beta^{\Delta 337 \mathrm{~T}}$ mice. (A) Relative heart weight (mg/cm); (B) left ventricular mass (mg); (C) end-systolic volume $(\mu \mathrm{L})$;

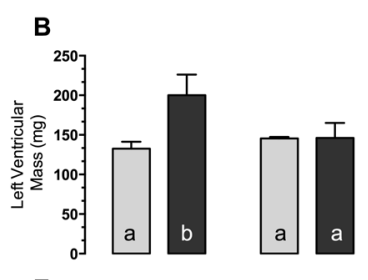

E

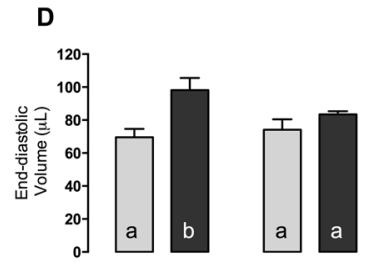

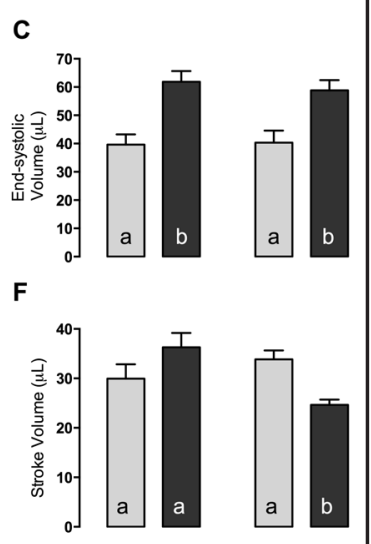

(D) end-diastolic volume $(\mu \mathrm{L})$; (E) ejection fraction (\%); (F) stroke volume $(\mu \mathrm{L})$. HYPO: PTU-treated mice, HYPER: PTU+T3-treated (higher dose) mice. See details in the Material and Methods section. The data are shown as the means \pm S.E.M. of at three independent experiments. Three to eleven animals were evaluated in each group. Same letters indicate similar means.

mice, respectively. As expected, the relative heart weight $(\mathrm{P}<0.001)$ and the left ventricular mass $(\mathrm{P}<0.05)$ significantly increased only in the TR $\beta^{\mathrm{WT}}$ mice after the T3 treatment (Fig. $4 \mathrm{~A}$ and $\mathrm{B}$ ). The TR $\beta^{\Delta 337 \mathrm{~T}}$ mice did not present with these changes, confirming the dilated hypertrophy. Any potential changes to cardiac contractility induced by these two different cardiac remodelling processes were assessed by examining the systolic function in the echocardiograms. A significant decrease in the systolic function was observed only in the $\mathrm{TR} \beta^{\Delta 337 \mathrm{~T}}$ mice treated with T3, accompanied with a significant reduction in the ejection fraction and stroke volume (Fig. 4E, $\mathrm{P}<0.001$; and $4 \mathrm{~F}, \mathrm{P}<0.05$ ). These results suggest that the $\operatorname{TR} \beta^{\Delta 337 \mathrm{~T}}$ mice developed heart failure in response to high T3 and the TR $\beta^{\mathrm{WT}}$ mice, as expected, did not.

\section{ECG analysis}

After the T3 treatment, the P-wave duration was significantly reduced in the TR $\beta^{\mathrm{WT}}$ mice $(\mathrm{P}<0.05)$. However, this decrease was not observed in the TR $\beta^{\triangle 337 \mathrm{~T}}$ mice (Table 4). The heart rate was significantly increased in both $\mathrm{T} 3$-treated groups $(\mathrm{P}<0.05)$. 


\section{Cellular Physiology Cell Physiol Biochem 2015;37:477-490

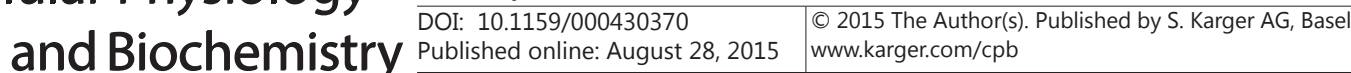 Imperio et al.: T3-Induced Cardiac Hypertrophy}

\section{Analysis of microRNA}

To investigate possible mechanisms involved in T3-induced cardiac hypertrophy, we first studied the ventricular expression of two well-known microRNAs, miR-1 and miR-208a, under the hypo- and hyperthyroid states (Fig. 5A and B). The expression of miR1 significantly increased in the TR $\beta^{\mathrm{WT}}$ and $\mathrm{TR} \beta^{\triangle 337 \mathrm{~T}}$ mice after $\mathrm{T} 3$ treatment $(\mathrm{P}<0.05$; Fig. 5A). However, miR-208a ventricular expression significantly increased only in the T3-treated TR $\beta^{\text {WT }}$ mice $(\mathrm{P}<0.05$, Fig. $5 \mathrm{~B})$.

We further investigated the broader miRNA profiles of these two groups. Unexpectedly, we found only a small number of miRNAs that were differently expressed in these groups (Fig. 6). Only nine miRNAs were differentially expressed $(p<0.05)$. Four miRNAs were down-regulated (miR-199a3p, miR-346-3p, miR-92b-3p, and miR-6516$5 \mathrm{p})$ and five were up-regulated (miR-568, miR-703, miR-713, miR-1231-5p, and miR$7219-3 p)$ in the TR $\beta^{\Delta 337 T}$ mice compared with the TR $\beta^{\mathrm{WT}}$ mice. We next used Ingenuity Systems Pathways Analysis software (IPA; Ingenuity Systems, CA, USA) to analyse in silico the significant differentially regulated miRNAs. Among the nine miRNAs analysed, only miR-199a-3p is known to be related to cardiac hypertrophy.

\section{Discussion}

This study evaluated in vivo and in silico the hypertrophic effects of thyroid hormone receptor $\beta$ (Thrb) on the expressions of key genes that are involved in the control of cardiac function and known to be directly regulated by T3 $[19,20,22,45-48]$. We showed that THR $\beta$ plays a fundamental role in cardiac hypertrophy induced by TH (Fig. 7). Concentric cardiac hypertrophy expected after T3 treatment was confirmed by the significant increases in the relative heart weight and the left ventricular mass and relative wall thickness in the TR $\beta^{\mathrm{WT}}$ mice, as indicated in pathology and echocardiograms. The absence of a functional THR $\beta$ leads to the dilated cardiomyopathy in the TR $\beta^{\Delta 337 \mathrm{~T}}$ mice in response to high T3 levels (Fig. 7). Different from the TR $\beta^{\mathrm{WT}}$ group, which maintained systolic function at physiological levels, the mutant animals showed decreased

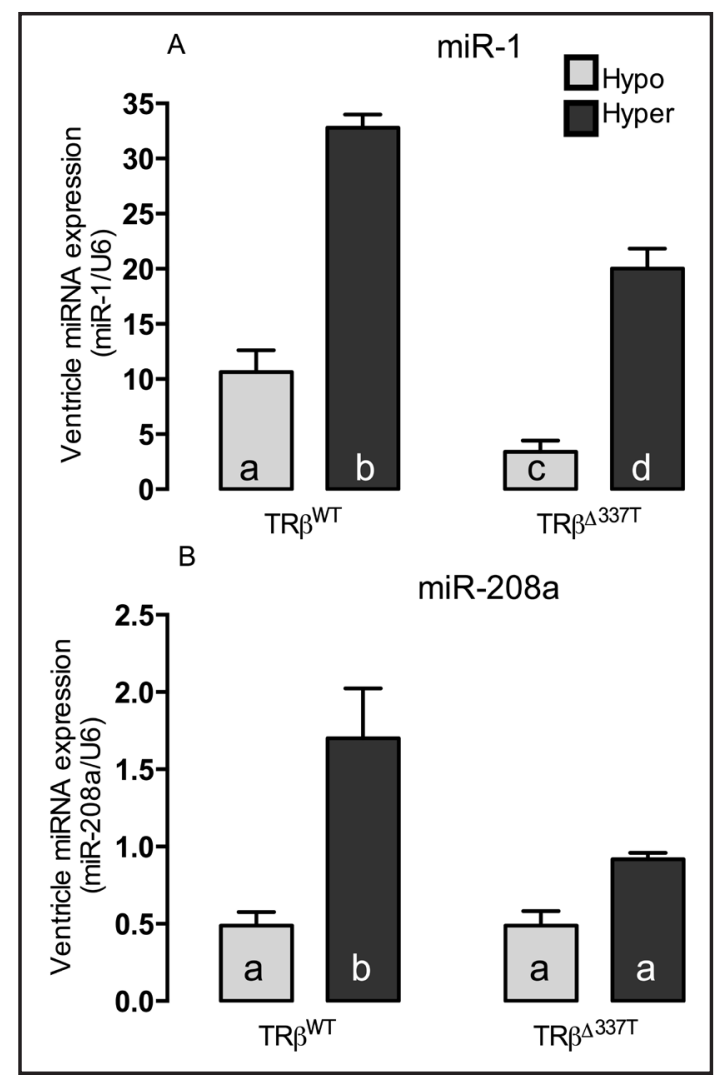

Fig. 5. Ventricular microRNA expression in TR $\beta^{\mathrm{WT}}$ and TR $\beta^{\Delta 337 T}$ mice according to qPCR analysis. (A) miR-1; (B) miR-208a expression. The data are shown as the means of fold change \pm S.E.M. Data were normalized for each miRNA level relative to the hypothyroid TR $\beta^{\mathrm{wt}}$. Same letters indicate similar means. Three animals were evaluated per group. HYPO: PTU-treated mice, HYPER: PTU+T3-treated mice.

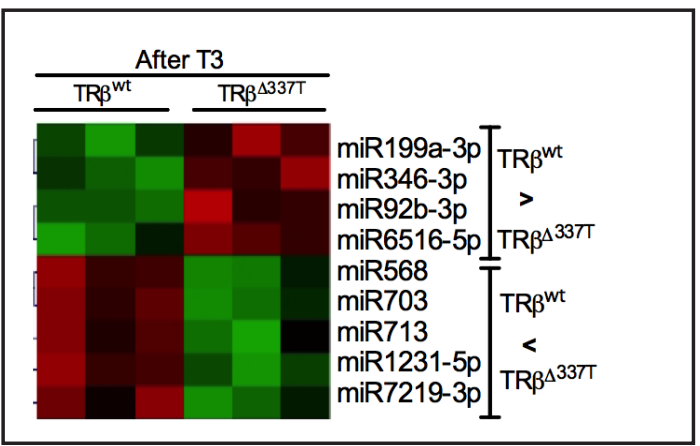

Fig. 6. Differentially expressed miRNAs in the ventricles of T3-treated TR $\beta^{\mathrm{WT}}$ and TR $\beta^{\Delta 337 \mathrm{~T}}$ mice. Mouse miRNA was analysed by LC Sciences (Houston, TX). Nine miRNAs were differentially expressed $(\mathrm{P}<0.05)$ : four miRNAs were down-regulated, and five were up-regulated in TR $\beta^{\Delta 337 T}$ mice compared with TR $\beta^{\mathrm{WT}}$. Three animals were evaluated per group. 
Fig. 7. Schematic representation of proposed role of THR $\beta$ in T3induced cardiac concentric hypertrophy. Myh6: $\alpha$ myosin heavy chain, Myh7: $\beta$ myosin heavy chain, Adrb1: $\beta 1$ adrenergic receptor, Adrb2: $\beta 2$ adrenergic receptor, Atp2a2: sarcoplasmic reticulum $\mathrm{Ca}^{++}$-ATPase $2 \mathrm{a}$, Hcn2: hyperpolarization-activated cyclic nucleotide-gated channels 2 , TRE: thyroid hormone response element.

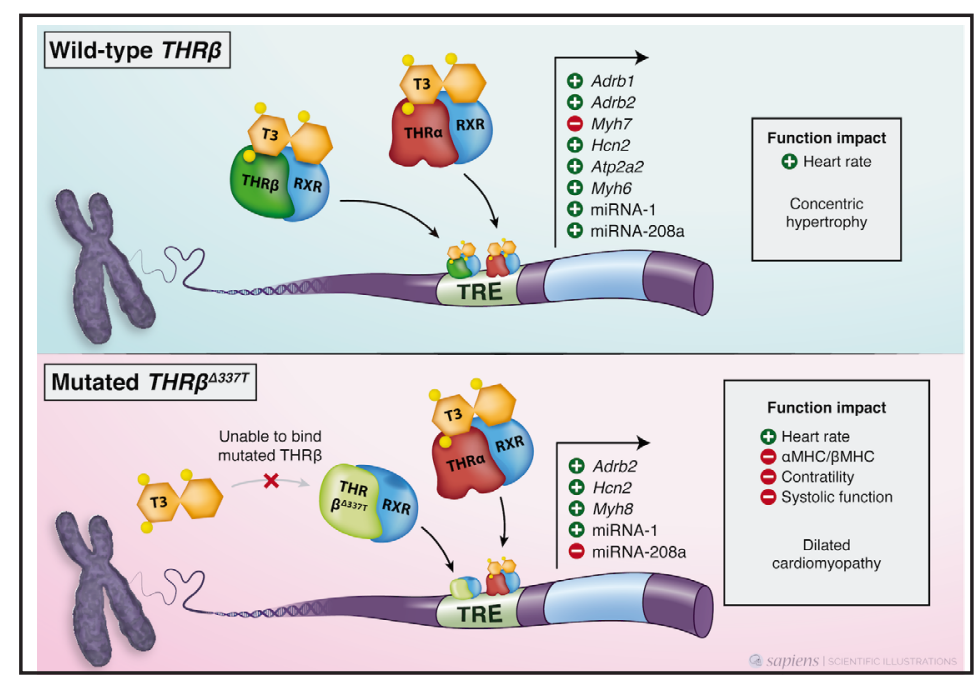

contractility and signs of heart failure as assessed by the echocardiographic exam. We and others have previously suggested that the Thrb mutation in heterozygotes could prevent an increase in the left ventricular mass induced by T3 $[13,45]$, indicating that blocking the binding of T3 to THR $\beta 1$ somehow interfered with the induction of cardiac concentric hypertrophy. To definitively demonstrate this mechanism, we analysed $\operatorname{TR} \beta^{\Delta 337 \mathrm{~T}}$ mice.

Because the TR $\beta^{\Delta 337 \mathrm{~T}}$ mice presented elevated serum concentrations of T4 and T3 [13, $14,24,42-44]$, it was necessary to normalize these hormone levels to investigate whether the changes found in the baseline gene expression were due to the absence of T3 binding to THR $\beta$ or to the increased THRA signalling. Additionally, as described below, a complex pattern of responses was observed where both isoforms of THRs had specific roles.

The hypertrophy induced by T3 in the WT mice was associated with a possible adaptive response, resulting in the stabilization of systolic function, whereas the TR $\beta^{\Delta 337 T}$ mice exhibited clear contractile deficits as assessed by echocardiography (Fig. 4). The increased mass of the left ventricle exhibited by the T3-treated TR $\beta^{\mathrm{WT}}$ mice was likely essential to maintain a normal cardiac output required by the high metabolic demand associated with hyperthyroidism. Moreover, the lack of functional T3/THR $\beta$ in the TR $\beta^{\triangle 337 T}$ HYPER group resulted in dilated cardiomyopathy and resulted in a clear reduction of systolic function (assessed in terms of ejection fraction and stroke volume) (Fig. 4). It is important to point out that $\mathrm{T} 3$ can bind normally to THR $\alpha 1$ in both groups.

A systemic effect caused by T3 bound to THR $\alpha 1$ (e.g., decreased afterload) in the maintenance of cardiac performance observed in the TR $\beta^{\mathrm{WT}}$ HYPER group should not be ruled out. It is possible that TR $\beta^{\Delta 337 T}$ HYPER mice were deprived of this effect, which would further increase the importance of THR $\beta$ in the regulation of systemic vascular resistance in the TR $\beta^{\Delta 337 T}$ HYPER group.

The contribution of the THRA isoform to the T3-induced cardiac hypertrophy was suggested in a previous study, wherein the over-expression of Thra1 in cardiomyocytes resulted in a hypertrophic phenotype, even in the absence of T3. THR $\beta 1$ played an inhibitory role in the activation of p38 MAPK and, hence, cardiac hypertrophy [49]. In addition, after a T3 treatment in a primary culture of rat cardiomyocytes, Kenessey and Ojamma described the involvement of THR $\alpha 1$ in a direct protein-protein interaction with PI3K in the cytosol, activating mTOR and promoting protein synthesis and cardiac hypertrophy [50]. The differences in the models and protocols may account for a few of the differences between our data and those found in the literature regarding the importance of different THR isoforms for T3-induced cardiac hypertrophy. Kinugawa's group used a Thra overexpression model, which may amplify (supraphysiologically) the T3/THR $\alpha$ signalling and overestimate the contribution of this pathway. In addition, although the involvement of THR $\alpha$ was unequivocally demonstrated for hypertrophy in both studies $[49,50]$, the studies used 


\section{Cellular Physiology Cell Physiol Biochem 2015;37:477-490 \\ \begin{tabular}{l|l} 
and Biochemistry Published online: August 28, 2015 & $\begin{array}{l}\text { C } 2015 \text { The Author(s). Published by S. Karger AG, Basel } \\
\text { www.karger.com/cpb }\end{array}$
\end{tabular} \\ Imperio et al.: T3-Induced Cardiac Hypertrophy}

cardiomyocyte cultures, which limit the physiological extrapolation of their results to the whole animal.

Kinugawa and colleagues have suggested that the expression of THRs in cardiac tissue was linked to the type of hypertrophic stimulus [49]. According to these authors, the THR $\beta$ isoform would be responsible for mediating a remodelling response because it was expressed at higher levels in cultures of cardiomyocytes treated with T3 and in vivo exercising animals. However, the THR $\alpha$ isoform would be responsible for mediating the pathological response because its expression was increased in the pathological cardiac hypertrophy models [51]. Thus, the mediation of cardiac hypertrophy by different receptor isoforms was not necessarily mutually exclusive with our findings and those of others $[13,45]$.

The increased $\alpha-\mathrm{MHC} / \beta-\mathrm{MHC}$ ratio induced by the T3 treatment in the TR $\beta^{\mathrm{WT}}$ mice was not observed in the TR $\beta^{\triangle 337 T}$ mice. A reduced $\alpha-\mathrm{MHC} / \beta-\mathrm{MHC}$ ratio may result in reduced ATPase activity and, thus, a lower contractile velocity in these animals. The down-regulation of Myh7 by T3 was impaired in the TR $\beta^{\Delta 337 \mathrm{~T}}$ mice (Fig. 3B), whereas Myh6 responded normally to T3 (Fig. 3A). The decreased $\alpha$-MHC/ $\beta$-MHC ratio (Fig. 3C) impaired the contractility profile, contributing to a drop in the ejection fraction and the stroke volume of the TR $\beta^{\Delta 337 \mathrm{~T}}$ animals, as observed in the echocardiograms (Fig. 4E and F).

Clearly, the T3 stimulation of Adrb1 mRNA was dependent on THR $\beta$ because there was a significant reduction in its expressions in the TR $\beta^{\Delta 337 \mathrm{~T}}$ mice between baseline levels (Fig. $1 \mathrm{~A}$ ) and after the T3 treatment (Fig. 2A). Similarly, THR $\beta$ is important in the regulation of Atp2a2 mRNA expression, as previously described (Fig. 1A and 2C) [51]. Moreover, when comparing the TR $\beta^{\mathrm{WT}}$ and TR $\beta^{\Delta 337 \mathrm{~T}}$ groups, regarding the absence or presence of T3, we observed that the $\mathrm{TR} \beta^{\mathrm{WT}}$ animals had higher Atp2a2 mRNA expression levels than the TR $\beta^{\Delta 337 \mathrm{~T}}$ animals, which may be reflected later in lower cardiac functional diastolic capacities, as was indeed observed in the echocardiograms (Fig. 2D and 4D). However, we cannot neglect the contribution of the Adrb1 receptors to the modulation of SERCA2, considering the lower expression of this receptor in the TR $\beta^{\Delta 337 \mathrm{~T}}$ mice. It is plausible to assume that the changes observed in Atp2a2 mRNA expression are due, at least in part, to decreased $\beta 1$-adrenergic signalling, either at baseline (Fig. 1A) or after T3 stimulation (Fig. 2C), which is also mediated by THR $\beta$.

Adrb2 and Hcn2 mRNA expressions are regulated by T3 independently of THR $\beta$ (Fig. $2 \mathrm{~B}$ and D) suggesting an important role of THR $\alpha 1$. HCNs are the channels responsible for the $I_{\mathrm{f}}$ (funny) current that permits cation $\left(\mathrm{Na}^{+}\right.$and $\left.\mathrm{K}^{+}\right)$passage when stimulated by plasma membrane hyperpolarization. The $\mathrm{I}_{\mathrm{f}}$ current is the main component of the slow diastolic depolarization phase of the action potential of sinus node cells. Even small reductions in HCN2 are sufficient to cause severe bradycardia [20]. The increase in Hcn2 mRNA atrial expression at baseline was expected (Fig. 2D) because we have previously observed that TR $\beta^{\Delta 337 \mathrm{~T}}$ mice exhibit significant increases in heart rate [52] under baseline conditions compared with $\mathrm{TR} \beta^{\mathrm{WT}}$ animals with a cardiac phenotype very similar to hyperthyroidism. This increased HR occurs because the TR $\beta^{\Delta 337 \mathrm{~T}}$ animals have high serum concentrations of $\mathrm{TH}$, which interact with THR $\alpha 1$. Thus, the presence of THR $\alpha 1$ results in an increased expression of Hcn2, which contributes to the increased HR and accounts for sinus tachycardia, a very common clinical sign in patients with RTH [53]. The increased HR in the TR $\beta^{\mathrm{WT}}$ and TR $\beta^{\Delta 337 \mathrm{~T}}$ mice after T3 treatment, as observed by ECG (Table 3), is associated with the Hcn2 mRNA atrial expression observed here (Fig. 2D) and agrees with previous studies that demonstrated that HCN2 and heart rate regulation occur via THR $\alpha$ and not via THR $\beta$ [20].

ECG also demonstrated a significant reduction of the P-wave duration in normal mice treated with T3 compared with hypothyroid mice. This effect of the T3 reducing the P-wave was absent in the TR $\beta^{\Delta 337 \mathrm{~T}}$ mice (Table 3 ), suggesting an important role for THR $\beta$ in the atrial conduction of these animals. Our group previously described that the up-regulation of Connexin 40 atrial gene expression exerted by TH was blocked by the over-expression of a non-functional dominant-negative THR $\beta$ in the heart [40]. However, when THR $\beta$ functionality was systemically compromised, as in our current transgenic animal model, the expression of Connexin 40 did not seem to be involved because there was no significant alteration in its expression in the TR $\beta^{\Delta 337 \mathrm{~T}}$ animals (data not shown). Thus, further studies 


\section{Cellular Physiology Cell Physiol Biochem 2015;37:477-490 \begin{tabular}{l|l|l|} 
and BOI: 10.1159/000430370 & $\begin{array}{l}\text { C) } 2015 \text { The Author(s). Published by S. Karger AG, Basel } \\
\text { www.karger.com/cpb }\end{array}$
\end{tabular} \\ Imperio et al.: T3-Induced Cardiac Hypertrophy}

are required to better understand the altered atrial conduction exhibited by TR $\beta^{\Delta 337 T}$ mice after T3 treatment.

Finally, to investigate the possible mechanisms involved in THR $\beta$-mediated cardiac hypertrophy, we evaluated the expression of two miRNAs: miR1, a muscle-specific miRNA expressed both in striated skeletal and cardiac muscles [54], and miR208a, which is exclusively expressed in cardiomyocytes [55]. Our analysis showed that, in cardiac tissue, TH up-regulates miR-1 expression, and this action occurs independently of THR $\beta$ because the same up-regulation was observed in both mice (Fig. 5A). It has been demonstrated that miR-1 attenuates cardiac hypertrophy [56]. However, in our model, there was no correlation between hypertrophy and miR-1 expression. Regarding miR-208a, we confirmed its upregulation by T3 $[28,29,57]$ and demonstrated that this effect was mediated by THR $\beta$ because T3 could not increase miR-208a in TR $\beta^{\Delta 337 \mathrm{~T}}$ mice (Fig. 5B). It has been reported that miR208a facilitates hypertrophic growth because it represses the expression of cardiac hypertrophy inhibitory proteins, such as myostatin and thyroid hormone-associated protein 1 (THRAP1) [29]. Thus, the findings that miR-208a induces hypertrophy and that its expression was similar to the profile observed for the relative heart weight (Fig. 4A) and ventricular mass (Fig. 4B) confirmed that miR-208a is involved in the induction of cardiac hypertrophy. Thus, when the binding of THR $\beta$ to T3 was blocked, the expected up-regulation of miR-208a was prevented. In turn, miR-208a was unable to repress the transcription factors inhibiting cardiac hypertrophy, resulting in the impairment of cardiac hypertrophy. Because very few studies exist concerning the involvement of THRs and miRNAs in T3induced hypertrophy [30,58], we evaluated the differences in the miRNA profiles of both groups after T3 treatment. Recently, Janssen et al. [58] found more than 50 differentially expressed mRNAs when hypothyroid mice were treated with an extremely high dose of T3 for 3 days. Surprisingly, we found only nine differently expressed miRNAs, indicating the specific role of THR $\beta$ in this regulation. After an IPA analysis, only miR-199a-3p, which was down-regulated in the TR $\beta^{\Delta 337 T}$ mice, was implicated in hypertrophy mechanisms. Although very little is known about the function of miR-199a-3p in the heart, it was shown that it is present in mice, rats, dogs and monkeys and in different cell types [27]. Although further investigation concerning the specific role of miR-208a and miR-199a-3p exceeds the scope of our work, this knowledge will be useful in the future because miRNAs can be used in therapeutic approaches to avoid damage in the heart of patients with increased levels of TH. In conclusion, as shown in Fig. 7, we suggested a crucial role for the regulation of specific mRNA and miRNA in T3-induced adaptive cardiac hypertrophic growth and alteration in heart functions mediated by THR $\beta$.

\section{Acknowledgements}

We thank the staff at the Laboratory of Translational Endocrinology and Molecular Endocrinology (UFRJ). This work was supported by FAPERJ (Fundação de Amparo à Pesquisa do Estado do Rio de Janeiro), Grant: 112.063/2012, 102.873/2012, Conselho Nacional de Desenvolvimento Científico e Tecnológico (CNPq: 303734/2012-4) and Coordenação de Aperfeiçoamento de Pessoal de Nível Superior (CAPES). We are in debt to the American Journal Experts (AJE) for English eddition and to Sapiens for image criation (Fig. 7).

\section{Disclosure Statement}

No conflicts of interest, financial or otherwise, are declared by the authors.

\section{References}

1 Ortiga-Carvalho TM, Sidhaye AR, Wondisford FE: Thyroid hormone receptors and resistance to thyroid hormone disorders. Nat Rev Endocrinol 2014;10:582-591.

2 Kahaly GJ, Dillmann WH: Thyroid hormone action in the heart. Endocr Rev 2005;26:704-728. 


\section{Cellular Physiology Cell Physiol Biochem 2015;37:477-490 \begin{tabular}{l|l} 
DOI: 10.1159/000430370 & $\begin{array}{l}\text { O 2015 The Author(s). Published by S. Karger AG, Basel } \\
\text { www.karger.com/cpb }\end{array}$
\end{tabular} \\ Imperio et al.: T3-Induced Cardiac Hypertrophy}

3 Bergh JJ, Lin HY, Lansing L, Mohamed SN, Davis FB, Mousa S, Davis PJ: Integrin alphaVbeta3 contains a cell surface receptor site for thyroid hormone that is linked to activation of mitogen-activated protein kinase and induction of angiogenesis. Endocrinology 2005;146:2864-2871.

4 Davis PJ, Davis FB, Lin HY, Mousa SA, Zhou M, Luidens MK: Translational implications of nongenomic actions of thyroid hormone initiated at its integrin receptor. Am J Physiol Endocrinol Metab 2009;297:E1238-1246.

5 Lin HY, Sun M, Tang HY, Lin C, Luidens MK, Mousa SA, Incerpi S, Drusano GL, Davis FB, Davis PJ: L-Thyroxine vs. 3,5,3'-triiodo-L-thyronine and cell proliferation: activation of mitogen-activated protein kinase and phosphatidylinositol 3-kinase. Am J Physiol Cell Physiol 2009;296:C980-991.

6 Cheng SY, Leonard JL, Davis PJ: Molecular aspects of thyroid hormone actions. Endocr Rev 2010;31:139170 .

7 Iordanidou A, Hadzopoulou-Cladaras M, Lazou A: Non-genomic effects of thyroid hormone in adult cardiac myocytes: relevance to gene expression and cell growth. Mol Cell Biochem 2010;340:291-300.

8 Axelband F, Dias J, Ferrao FM, Einicker-Lamas M: Nongenomic signaling pathways triggered by thyroid hormones and their metabolite 3-iodothyronamine on the cardiovascular system. J Cell Physiol 2011;226:21-28.

9 Dillmann W: Cardiac hypertrophy and thyroid hormone signaling. Heart Fail Rev 2010;15:125-132.

10 Ojamaa K: Signaling mechanisms in thyroid hormone-induced cardiac hypertrophy. Vascul Pharmacol 2010;52:113-119.

11 Klein I, Ojamaa K: Thyroid hormone and the cardiovascular system. N Engl J Med 2001;344:501-509.

12 Dillmann WH, Gloss BR: The role of thyroid hormone receptors in the heart. Methods Mol Biol 2002;202:55-70.

13 Ortiga-Carvalho TM, Hashimoto K, Pazos-Moura CC, Geenen D, Cohen R, Lang RM, Wondisford FE: Thyroid hormone resistance in the heart: role of the thyroid hormone receptor beta isoform. Endocrinology 2004;145:1625-1633.

14 Pessoa CN, Santiago LA, Santiago DA, Machado DS, Rocha FA, Ventura DF, Hokoc JN, Pazos-Moura CC, Wondisford FE, Gardino PF, Ortiga-Carvalho TM: Thyroid hormone action is required for normal cone opsin expression during mouse retinal development. Invest Ophthalmol Vis Sci 2008;49:2039-2045.

15 Souza LL, Cordeiro A, Oliveira LS, de Paula GS, Faustino LC, Ortiga-Carvalho TM, Oliveira KJ, Pazos-Moura CC: Thyroid hormone contributes to the hypolipidemic effect of polyunsaturated fatty acids from fish oil: in vivo evidence for cross talking mechanisms. J Endocrinol 2011;211:65-72.

16 de Andrade Pinto AC, Barbosa CM, Ornellas DS, Novaira HJ, de Souza-Menezes J, Ortiga-Carvalho TM, Fong P, Morales MM: Thyroid hormones stimulate renal expression of CFTR. Cell Physiol Biochem 2007;20:8390.

17 Wei JY, Spurgeon HA, Lakatta EG: Excitation-contraction in rat myocardium: alterations with adult aging. Am J Physiol 1984;246:H784-791.

18 Yin FC, Spurgeon HA, Rakusan K, Weisfeldt ML, Lakatta EG: Use of tibial length to quantify cardiac hypertrophy: application in the aging rat. Am J Physiol 1982;243:H941-947.

19 Weiss RE, Murata Y, Cua K, Hayashi Y, Seo H, Refetoff S: Thyroid hormone action on liver, heart, and energy expenditure in thyroid hormone receptor beta-deficient mice. Endocrinology 1998;139:4945-4952.

20 Gloss B, Trost S, Bluhm W, Swanson E, Clark R, Winkfein R, Janzen K, Giles W, Chassande O, Samarut J, Dillmann W: Cardiac ion channel expression and contractile function in mice with deletion of thyroid hormone receptor alpha or beta. Endocrinology 2001;142:544-550.

21 Johansson C, Gothe S, Forrest D, Vennstrom B, Thoren P: Cardiovascular phenotype and temperature control in mice lacking thyroid hormone receptor-beta or both alpha1 and beta. Am J Physiol 1999;276:H2006-2012.

22 Swanson EA, Gloss B, Belke DD, Kaneshige M, Cheng SY, Dillmann WH: Cardiac expression and function of thyroid hormone receptor beta and its PV mutant. Endocrinology 2003;144:4820-4825.

23 Usala SJ, Menke JB, Watson TL, Berard WE, Bradley C, Bale AE, Lash RW, Weintraub BD: A new point mutation in the 3,5,3'-triiodothyronine-binding domain of the c-erbA beta thyroid hormone receptor is tightly linked to generalized thyroid hormone resistance. J Clin Endocrinol Metab 1991;72:32-38.

24 Hashimoto K, Curty FH, Borges PP, Lee CE, Abel ED, Elmquist JK, Cohen RN, Wondisford FE: An unliganded thyroid hormone receptor causes severe neurological dysfunction. Proc Natl Acad Sci U S A 2001;98:39984003. 


\section{Cellular Physiology Cell Physiol Biochem 2015;37:477-490 \begin{tabular}{l|l|l} 
and Biochemistry 10.1159/000430370 & $\begin{array}{l}\text { C } 2015 \text { The Author(s). Published by S. Karger AG, Basel } \\
\text { www.karger.com/cpb }\end{array}$
\end{tabular} \\ Imperio et al.: T3-Induced Cardiac Hypertrophy}

25 Small EM, Olson EN: Pervasive roles of microRNAs in cardiovascular biology. Nature 2011;469:336-342.

26 Zhao Y, Ransom JF, Li A, Vedantham V, von Drehle M, Muth AN, Tsuchihashi T, McManus MT, Schwartz RJ, Srivastava D: Dysregulation of cardiogenesis, cardiac conduction, and cell cycle in mice lacking miRNA-1-2. Cell 2007;129:303-317.

27 Vacchi-Suzzi C, Hahne F, Scheubel P, Marcellin M, Dubost V, Westphal M, Boeglen C, Buchmann-Moller S, Cheung MS, Cordier A, De Benedetto C, Deurinck M, Frei M, Moulin P, Oakeley E, Grenet O, Grevot A, Stull R, Theil D, Moggs JG, Marrer E, Couttet P: Heart structure-specific transcriptomic atlas reveals conserved microRNA-mRNA interactions. PLoS One 2013;8:e52442.

28 van Rooij E, Sutherland LB, Qi X, Richardson JA, Hill J, Olson EN: Control of stress-dependent cardiac growth and gene expression by a microRNA. Science 2007;316:575-579.

29 Callis TE, Pandya K, Seok HY, Tang RH, Tatsuguchi M, Huang ZP, Chen JF, Deng Z, Gunn B, Shumate J, Willis MS, Selzman CH, Wang DZ: MicroRNA-208a is a regulator of cardiac hypertrophy and conduction in mice. J Clin Invest 2009;119:2772-2786.

30 Tu Y, Wan L, Bu L, Zhao D, Dong D, Huang T, Cheng Z, Shen B: MicroRNA-22 downregulation by atorvastatin in a mouse model of cardiac hypertrophy: a new mechanism for antihypertrophic intervention. Cell Physiol Biochem 2013;31:997-1008.

31 Santiago LA, Santiago DA, Faustino LC, Cordeiro A, Lisboa PC, Wondisford FE, Pazos-Moura CC, OrtigaCarvalho TM: The \{Delta\}337T mutation on the TR \{beta\} causes alterations in growth, adiposity and hepatic glucose homeostasis in mice. J Endocrinol 2011;211:39-46.

32 Bianco AC, Anderson G, Forrest D, Galton VA, Gereben B, Kim BW, Kopp PA, Liao XH, Obregon MJ, Peeters RP, Refetoff S, Sharlin DS, Simonides WS, Weiss RE, Williams GR, American Thyroid Association Task Force on A, Strategies to Investigate Thyroid Hormone E, Action: American Thyroid Association Guide to investigating thyroid hormone economy and action in rodent and cell models. Thyroid 2014;24:88-168.

33 Nachar W, Busseuil D, Shi Y, Mihalache-Avram T, Mecteau M, Rheaume E, Tardif JC: Optimisation of reference genes for gene-expression analysis in a rabbit model of left ventricular diastolic dysfunction. PLoS One 2014;9:e89331.

34 Machado DS, Sabet A, Santiago LA, Sidhaye AR, Chiamolera MI, Ortiga-Carvalho TM, Wondisford FE: A thyroid hormone receptor mutation that dissociates thyroid hormone regulation of gene expression in vivo. Proc Natl Acad Sci U S A 2009;106:9441-9446.

35 Faustino LC, Almeida NA, Pereira GF, Ramos RG, Soares RM, Morales MM, Pazos-Moura CC, Ortiga-Carvalho TM: Thyroid hormone and estradiol have overlapping effects on kidney glutathione S-transferase-alpha gene expression. Am J Physiol Endocrinol Metab 2012;303:E787-797.

36 Livak KJ, Schmittgen TD: Analysis of relative gene expression data using real-time quantitative PCR and the 2(-Delta Delta C(T)) Method. Methods 2001;25:402-408.

37 Pfaffl MW: A new mathematical model for relative quantification in real-time RT-PCR. Nucleic Acids Res 2001;29:e45.

38 Quinones MA, Otto CM, Stoddard M, Waggoner A, Zoghbi WA, Doppler Quantification Task Force of the $\mathrm{N}$, Standards Committee of the American Society of E: Recommendations for quantification of Doppler echocardiography: a report from the Doppler Quantification Task Force of the Nomenclature and Standards Committee of the American Society of Echocardiography. J Am Soc Echocardiogr 2002;15:167-184.

39 Schiller NB, Shah PM, Crawford M, DeMaria A, Devereux R, Feigenbaum H, Gutgesell H, Reichek N, Sahn D, Schnittger I, et al.: Recommendations for quantitation of the left ventricle by two-dimensional echocardiography. American Society of Echocardiography Committee on Standards, Subcommittee on Quantitation of Two-Dimensional Echocardiograms. J Am Soc Echocardiogr 1989;2:358-367.

40 Almeida NA, Cordeiro A, Machado DS, Souza LL, Ortiga-Carvalho TM, Campos-de-Carvalho AC, Wondisford FE, Pazos-Moura CC: Connexin40 messenger ribonucleic acid is positively regulated by thyroid hormone (TH) acting in cardiac atria via the TH receptor. Endocrinology 2009;150:546-554.

41 Oliveira KJ, Ortiga-Carvalho TM, Cabanelas A, Veiga MA, Aoki K, Ohki-Hamazaki H, Wada K, Wada E, PazosMoura CC: Disruption of neuromedin B receptor gene results in dysregulation of the pituitary-thyroid axis. J Mol Endocrinol 2006;36:73-80.

42 Portella AC, Carvalho F, Faustino L, Wondisford FE, Ortiga-Carvalho TM, Gomes FC: Thyroid hormone receptor beta mutation causes severe impairment of cerebellar development. Mol Cell Neurosci 2010;44:68-77. 


\section{Cellular Physiology Cell Physiol Biochem 2015;37:477-490 \begin{tabular}{l|l|l} 
and Biochemistry & DoI: 10.1159/000430370 & $\begin{array}{l}\text { C } 2015 \text { The Author(s). Published by S. Karger AG, Basel } \\
\text { www.karger.com/cpb }\end{array}$
\end{tabular} \\ Imperio et al.: T3-Induced Cardiac Hypertrophy}

43 Santiago LA, Santiago DA, Faustino LC, Cordeiro A, Lisboa PC, Wondisford FE, Pazos-Moura CC, OrtigaCarvalho TM: The Delta337T mutation on the TRbeta causes alterations in growth, adiposity, and hepatic glucose homeostasis in mice. J Endocrinol 2011;211:39-46.

44 Faustino LC, Pires RM, Lima AC, Cordeiro A, Souza LL, Ortiga-Carvalho TM: Liver glutathione S-transferase expression is decreased by 3,5,3-triiodothyronine in hypothyroid but not in euthyroid mice. Exp Physiol 2011;96:790-800.

45 Weiss RE, Korcarz C, Chassande O, Cua K, Sadow PM, Koo E, Samarut J, Lang R: Thyroid hormone and cardiac function in mice deficient in thyroid hormone receptor-alpha or -beta: an echocardiograph study. Am J Physiol Endocrinol Metab 2002;283:E428-435.

46 Wikstrom L, Johansson C, Salto C, Barlow C, Campos Barros A, Baas F, Forrest D, Thoren P, Vennstrom B: Abnormal heart rate and body temperature in mice lacking thyroid hormone receptor alpha 1 . Embo J 1998;17:455-461.

47 Hartong R, Wang N, Kurokawa R, Lazar MA, Glass CK, Apriletti JW, Dillmann WH: Delineation of three different thyroid hormone-response elements in promoter of rat sarcoplasmic reticulum Ca2+ATPase gene. Demonstration that retinoid X receptor binds 5' to thyroid hormone receptor in response element 1. J Biol Chem 1994;269:13021-13029.

48 Gloss B, Sayen MR, Trost SU, Bluhm WF, Meyer M, Swanson EA, Usala SJ, Dillmann WH: Altered cardiac phenotype in transgenic mice carrying the delta337 threonine thyroid hormone receptor beta mutant derived from the S family. Endocrinology 1999;140:897-902.

49 Kinugawa K, Jeong MY, Bristow MR, Long CS: Thyroid hormone induces cardiac myocyte hypertrophy in a thyroid hormone receptor alpha1-specific manner that requires TAK1 and p38 mitogen-activated protein kinase. Mol Endocrinol 2005;19:1618-1628.

50 Kenessey A, Ojamaa K: Thyroid hormone stimulates protein synthesis in the cardiomyocyte by activating the Akt-mTOR and p70S6K pathways. J Biol Chem 2006;281:20666-20672.

51 Kinugawa K, Yonekura K, Ribeiro RC, Eto Y, Aoyagi T, Baxter JD, Camacho SA, Bristow MR, Long CS, Simpson PC: Regulation of thyroid hormone receptor isoforms in physiological and pathological cardiac hypertrophy. Circ Res 2001;89:591-598.

52 Derda AA, Thum S, Lorenzen JM, Bavendiek U, Heineke J, Keyser B, Stuhrmann M, Givens RC, Kennel PJ, Christian Schulze P, Widder JD, Bauersachs J, Thum T: Blood-based microRNA signatures differentiate various forms of cardiac hypertrophy. Int J Cardiol 2015;196:115-122.

53 Dumitrescu AM, Refetoff S: The syndromes of reduced sensitivity to thyroid hormone. Biochim Biophys Acta 2013;1830:3987 - 4003.

54 Zhao Y, Samal E, Srivastava D: Serum response factor regulates a muscle-specific microRNA that targets Hand2 during cardiogenesis. Nature 2005;436:214-220.

55 Fichtlscherer S, Zeiher AM, Dimmeler S: Circulating microRNAs: biomarkers or mediators of cardiovascular diseases? Arterioscler Thromb Vasc Biol 2011;31:2383-2390.

56 Ikeda S, He A, Kong SW, Lu J, Bejar R, Bodyak N, Lee KH, Ma Q Kang PM, Golub TR, Pu WT: MicroRNA-1 negatively regulates expression of the hypertrophy-associated calmodulin and Mef2a genes. Mol Cell Biol 2009;29:2193-2204.

57 Diniz GP, Takano AP, Barreto-Chaves ML: miRNA-208a and miRNA-208b are triggered in thyroid hormoneinduced cardiac hypertrophy - Role of type 1 Angiotensin II receptor (AT1R) on miRNA-208a/alpha-MHC modulation. Mol Cell Endocrinol 2013;374:117-124.

58 Janssen R, Zuidwijk MJ, Kuster DW, Muller A, Simonides WS: Thyroid Hormone-Regulated Cardiac microRNAs are Predicted to Suppress Pathological Hypertrophic Signaling. Front Endocrinol (Lausanne) 2014;5:171.

59 Lefrere I, De Coppet P, Camelin JC, Le Lay S, Mercier N, Elshourbagy N, Bril A, Berrebi-Bertrand I, Feve B, Krief S: Neuropeptide AF and FF modulation of adipocyte metabolism. Primary insights from functional genomics and effects on beta-adrenergic responsiveness. J Biol Chem 2002;277:39169-39178.

60 Louch WE, Vangheluwe P, Bito V, Raeymaekers L, Wuytack F, Sipido KR: Phospholamban ablation in hearts expressing the high affinity SERCA2b isoform normalizes global $\mathrm{Ca}(2)(+)$ homeostasis but not $\mathrm{Ca}(2)$ (+)-dependent hypertrophic signaling. Am J Physiol Heart Circ Physiol 2012;302:H2574-2582.

61 Chen WJ, Lin KH, Lee YS: Molecular characterization of myocardial fibrosis during hypothyroidism: evidence for negative regulation of the pro-alpha1(I) collagen gene expression by thyroid hormone receptor. Mol Cell Endocrinol 2000;162:45-55. 